\title{
The Element of Deliberate Action in a Series of Actions on PRONA Program's Corruption Crime
}

\section{Antonius Agung Ariyanto*) and Ira Alia Maerani**)}

*) Student of Master of Law, Faculty of Law, Universitas Islam Sultan Agung Semarang, Indonesia, E-mail: agungariyanto1974.aa@gmail.com

${ }^{* *}$ ) Faculty of Law Universitas Islam Sultan Agung

\begin{abstract}
.
The purpose of this research is to analyze construction law panel of judges in deciding cases of corruption, qualifying extortion in the PRONA program. The research approach method used is a qualitative normative juridical approach. The legal construction built by the Panel of Judges in criminal cases of extortion qualification of corruption fulfills the provisions in Criminal Law, namely the Principles of Legality and culpability. The defendant was proven to have violated the law in the provisions charged by the public prosecutor, namely Act No. 31 of 1999 Jo Act No. 20 of 2001 and Article 55 paragraph (1) to 1 of the Criminal Code. The conclusion of this research is that the defendant was proven intentionally, at least knowing it as an intentional element, designing the Prona committee, determining Prona's fees, and issuing a "threat" letter to the applicant which should be free (with certain conditions). According to the Panel of Judges, such legal facts are sufficient to prove that the defendant was deliberately involved in the criminal act of corruption. It is recommended that in dealing with corruption cases with the same motive, in the future, the public prosecutor is more courageous in giving a single indictment. So that from the start, I was sure of the charges given, especially from the collection of materials and information through a catch operation. Keywords: Legal Construction; Corruption; Extortion.
\end{abstract}

\section{Introduction}

Corruption, according to the United Nation Convention Against Corruption (UNCAC), is formulated as a threat to the security and stability of society, damages democratic values and institutions, destroys moral values and justice, endangers sustainable development and the 'rule of law' and threatens stability political. ${ }^{1}$ This means that corruption is an extra ordinary crime, which requires extraordinary efforts to eradicate it. In addition, it is necessary to implement a policy to combat corruption through an integral (integrated) and comprehensive approach. Hulman also argued corruption is an act that can cause losses to many parties and can even affect the existence and development of progress and the welfare of the people of a country. ${ }^{2}$ People, as victims of corruption (although sometimes unwittingly), yearn for sustainable development towards prosperity that can be felt real in the beats of life. However, corruption was increasingly prevalent in the post-New Order era. The various modus operandi which are

\footnotetext{
1 Arief, Barda Nawawi. Kebijakan Reformulasi Ancaman Pidana Mati Tindak Pidana Korupsi dalam Peraturan Perundang-Undangan, MMH, Jilid 42, January 1, 2013. p.1.

2 Siregar, Hulman. Rumusan Pidana Dan Pemidanaan Tindak pidana Korupsi Yang Merugikan Keuangan Negara Serta Permasalaan Dalam Penerapannya, Jurnal Daulat Hukum Volume 1 No. 1 March 2018, p. 126.
} 
increasingly sophisticated, seem to have participated in the increasingly auto matic technological changes. The level of awareness of the public mind is carried away by the flow of collective memory that corruption is considered normal, commonplace and all other views that have a nuance of despair. This is in line with Selamet and Djauhari's statement that corruptionis a crime which in quality and quantity continues to increase. ${ }^{3}$

The fact that corruption destroys the joints of society, nation and state is a classic problem which has not been resolved until now. For this reason, the law exists as a means for us to tackle criminal acts of corruption. In the current regulation the provisions are clearly regulated in Act No.31 of 1999 Jo Act No. 20 of 2001 concerning the Eradication of Corruption Crimes. Even though there are several weaknesses in the Corruption Law, overall it is still sufficient as a legal substance to eradicate corruption. Government policies cannot be separated from legal policies because we adhere to the principles of the rule of law. The policy principle implemented by the government hides in it legal policy. Philosophical aspects of law contain the value of justice. Juridical aspect means legal certainty. The sociological aspect contains benefits. The integrity of each government policy combined with the legal policies in it, creates synergy in the three aspects of the law. In essence, the Criminal policy tool (Penal Law) moves to guard the values in philosophy, guarantees legal certainty (juridical) and ensures the maximum benefit of the people's welfare (sociological).

The National Agrarian Operation Project Policy (Prona), is a mass and integrated land certification process. The aim of this program is to provide firsttime land registration services with a simple, easy, fast, and inexpensive process in order to accelerate land registration. The implementation of the Prona program still leaves a gap in the correlative factor of the criminal act of corruption. For this reason, researchers are interested in examining in depth the facts of events and legal facts to the verdict of the panel of judges regarding the criminal case of extortion qualification corruption in the frame of deviation from the implementation of Prona's policies. As for this Prona set in Permen ATR / BPN No. 4 of 2015. Thus, the researcher departs from the formulation of the problem: How is the construction law panel of judges in deciding cases of criminal corruption with the qualifications of extortion in case Number 21 / Pid.Sus-TPK / 2018 / PN Smg? As an initial description of the discussion or answers to these problems, the researcher focuses on the Legal Structure subsystem (StructureLaw) borrows a definition from Lawrence M. Friedman of his Legal System Theory. So that the writer chose to analyze the arguments of the panel of judges in deciding the case. As a free and independent Judicial Authority, the verdict of the panel of judges is one of the sourceslaw living in today's society (law positive).

\section{Research methods}

The study method in formulating a solution uses normative juridical in a broad and narrow sense. According to Koko and Sri Endah, by using normative

\footnotetext{
${ }^{3}$ Djauhari, and Selamet Agista Erikha Bhakti. Upaya Pencegahan Tindak Pidana Korupsi Melalui Peran Serta Masyarakat, Jurnal Hukum Khaira Ummah, Vol. 12. No. 2 June 2017. p. 307.
} 
juridical researchers will be able to find the truth using inductive methods and criteria for measuring a fact in accordance with proper legal studies. ${ }^{4}$ If what is seen is not only the relationship with the mere set of norms, but especially views the importance of the social effects of the formation of norms (law) so that the importance of social background is seen, then it is called normative juridical method in a broad sense. ${ }^{5}$ When discussing the juridical formulation in the provisions of the Corruption Qualification Extortion, the approach used is normative juridical in a narrow sense. So that the entirety of this article is related to the normative juridical method, both in broad and narrow terms. This research uses a qualitative approach, which is an approach that emphasizes inductive analysis, descriptive analysis, and the study of people's perceptions or opinions. ${ }^{6}$ The researcher emphasizes in more detail the detailed aspects of the legal construction built by the panel of judges. Critically analyze and use case studies on the case.

\section{Results and Discussion}

\section{Corruption Case Qualification Extortion Decision Number 21 / Pid.Sus-TPK / 2018 / PN Smg.}

\section{Indictment}

Charged with violating the provisions of Article 12 letter e Act No. 31 of 1999 as amended and added to Act No. 20 of 2001 Jo. Article 55 Paragraph (1) 1 of the Criminal Code according to the indictment.

\section{Case Position}

The defendant MHP bin SAM (Alm) committed a criminal act of corruption by breaking the law forcing someone to pay in connection with the implementation of the Project Prona. The witness's testimony stated "If the community who is petitioning for a certificate does not heed / has good ethics, the committee will force it Prona The village will come to you and take it back from you or it will be blocked. " Apart from that Project Pronawhich is held free of charge but there are fees charged to the residents, namely for the purchase of stamps, stamps, photocopies of applicants' files, travel costs, drawing sketches, writing documents, rough measurements, overtime searching for nomonative $\mathrm{C} / \mathrm{C}$ village data and the origin of land, completeness of documents such as SPPT Tax, KTP, KK, other required documents. The defendant is included in the definition of a "civil servant" who has sufficient evidence that he is suspected of jointly committing corruption with the intention of benefiting himself or others, illegally and abusing his power as Village head and Chairman of the Prona Committee by establishing policies that are not in accordance with the applicable provisions used as a basis for levies or force someone to pay IDR 600,000 per plot of land and IDR 750.Prona).

\footnotetext{
4 Sri Endah Wahyuningsih, and Koko Arianto Wardani. Kebijakan Formulasi Hukum Pidana Mati Terhadap Pelaku Tindak Pidana Korupsi Di Indonesia, Jurnal Hukum Khaira Ummah, Vol. 12. No. 4 December 2017.p. 953.

${ }^{5}$ Sudarto. (1981). Hukum dan Hukum Pidana. Bandung: Alumni. p.13.

${ }^{6}$ L.J, Moleong. (2004). Metodologi Penelitian. Bandung: Remaja Rosda Karya. p. 3.
} 
Article 12 letter e Act No. 20 of 2001, the juridical formulation of the article is as follows: Sentenced to life imprisonment or imprisonment for a minimum of 4 years and a maximum of 20 years and a fine of at least IDR 200,000,000 and a maximum of IDR 1,000 .000,000. Then inclusion in a criminal offense Article 55 Paragraph (1) 1 of the Criminal Code, the juridical formulation is as follows: Convicted as the perpetrator of a criminal act: those who commit, order to commit, and who participate in the act.

\section{Decision}

Based on decision Number 21 / Pid.Sus-TPK / 2018 / PN Smg, the Panel of Judges decided : ${ }^{7}$

- Stated that the Defendant was legally and convincingly proven guilty of committing "Corruption Crime Together.

- Sentenced the defendant to 4 years imprisonment, as well as a fine of IDR200,000,000.00, provided that if the penalty is not paid, it is replaced by imprisonment for 3 months.

- To stipulate that the entire length of time the Defendant is in arrest and / or detention is deducted from the imprisonment imposed.

- To stipulate that the Defendant would remain in detention.

- To charge the Defendant to pay court fees amounting to IDR 5,000.00.

Proof

In accordance with the facts law during the trial and valid evidence as regulated in Article 184 paragraph (2) of the Criminal Procedure Code in the form of a witness to Defendant, is proven to have committed corruption. Through evidence, the single indictment violates Article 12 letter e of Act No. 31 of 1999 jo. Act No. 20 of 2001 in conjunction with Article 55 Paragraph (1) 1st of the Criminal Code, the elements of which are as follows:

- Civil Servants or State Administrators;

The defendant was the Village head and also the Chairman of the Prona Committee. The defendant also received income every month which came from the Village Fund Allocation and Village Original Income. Based on legal facts, it is clear that the Defendant is a "civil servant" as referred to in Article 1 paragraph (2) letter $\mathrm{c}$ of Act No. 31 of 1999. Then the first element has been fulfilled.

- With the intention of benefiting yourself or others;

According to the Court, the word "with a purpose" in the second element of Article 3 of Act No. 31 of 1999 in conjunction with Act No. 20 of 2001, indicates that there is a will in the mind of the maker, to obtain an advantage for himself or others. So when the action is to be carried out, it is required that there is an intention or will or intention in the perpetrator for the occurrence of gain, either benefiting himself or benefiting others. According to the Court, what is meant by "profitable" is not limited to obtaining an advantage in the form of money or assets, but also in the form of obtaining facilities, facilities such as commissions, discounted prices or other priorities.

\footnotetext{
${ }^{7}$ Berkas Perkara 21/Pid.Sus-TPK/2018/PN Smg.
} 
In November 2016, an announcement was issued regarding the requirements for Prona's certification, including: Photocopy of KTP, KK, SPPT, a fee of IDR 600,000 for yards and IDR 750,000 for rice fields. Thus, it appears that the Defendant's actions determined the costs that must be borne by the applicant for completing the requirements or documents for making land certificates for Prona participants, without being based on the price that should have been issued according to a reasonable and reasonable price so that there was a mark up, among others for costs: stakes, installation of stakes, photocopies, and is used for unnecessary costs such as the cost of checking the location and making rough sketches, filling out forms, making finished and boundary drawings, stationery and printed materials, meetings and outreach, witnesses, source search C Village, consumption of internal activities,

The actions of the Defendant who took the decision to determine the costs to be borne by the Prona participants were by taking advantage of the participants' ignorance of the amount of obligations that were the responsibility of the participants and not going through deliberation, and using the money collected for other interests that were not related to the implementation of land certification. So that from the money collected IDR228,325,000, it is not used in accordance with the designation, namely received and distributed to parties and / or for activities that are not supposed to be in the amount of IDR banners and meals and administration of Bintek Posdaya to Jogja, the village head for the shortage of PKK competitions, paid for 3 rites of graft, bought 2 sacks of plaster for office doors, a meeting to Boyolali, NGO Press Anniversary, paid for electricity, sir,

The actions above are "intentional", because they are carried out consciously and surely knowing the intent of carrying out these actions, namely that the Prona participants submit the process of making land certificates to the Prona Committee, and then the Committee gets rewarded for managing services and carrying out Prona's activities. So that it clearly illustrates the intention to benefit yourself and other parties. This is in line with the theory of Adrian Sutedi, ${ }^{8}$ which explains that corruption refers to various hidden and illegal activities or actions to gain profit for personal or group interests.

- Unlawfully or abusing their power;

What is meant by "abusing one's power" is using power for a purpose other than the purpose for which it was granted ". When it is related to the a quo corruption crime, "abusing one's power" means "using the power attached to the position or position held or occupied by the perpetrator of the criminal act of corruption for other purposes than the granting of that power, to achieve the goal of benefiting himself or others. The provisions of Article 15 paragraph (2) letter $b$ Chapter IV Permen ATR / BPN Number 35 of 2016, it is stated that "the financing that comes from the government comes from the DIPA of the Ministry of Agrarian and Spatial Planning / National Land Agency and / or other ministries / government agencies"

Cost is determined without being based on clear rules, and not based on reasonable prices, and not through deliberation with participants, but directly

\footnotetext{
${ }^{8}$ Sutedi, Adrian. (2009). Aspek Hukum Pengadaan Barang dan Jasa dan Berbagai Permasalahannya. Jakarta : Sinar Grafika. p. 80.
} 
determining the amount of costs to be borne by participants by taking advantage of participants' ignorance. As the Chairperson of Prona, the Defendant did not follow the rules intended for the activity, so the act was considered an act against the law and / or an abuse of power. The deed determines the amount of the cost of making a certificate that is not based on a clear legal basis, so that there is a mark up and price inflation that is not in accordance with the price it should be.

- Forcing someone to give something, pay or receive a discounted payment or to do something for himself.

The act of the Defendant who made a letter, which obliged all participants to pay a stipulated fee with the threat that if the fee was not paid, the certificate issued would be blocked was clearly an act of "forcing someone to give something, pay, receive a discounted payment or to do something for himself ". It was strengthened again by the objections submitted by the participants to the unilateral decision by the Prona Team, namely by reporting coercion to the authorities.

- Element: "As a person who does, who orders to do or participates in doing an action".

The provisions of Article 55 paragraph (1) 1 of the Criminal Code, which can be convicted as a "Criminal Actor" is a person who commits the crime himself (pleger), or a person who orders a criminal act (doenpleger), or a person who participates in the crime. a criminal act (medepleger). There was a series of actions committed by the Defendant together with witness $\mathrm{AK}$ as Treasurer, $\mathrm{P}$ as Secretary, SHS as Village Head and Person in ChargeProna. From the series of acts, it can be seen that there is close cooperation and cannot be separated from one another, in other words the criminal act cannot be committed alone. It is clear that the occurrence of a criminal act in this case each of the perpetrators has committed the main elements of the offense charged, so that the act is included in the category of criminal offender as desired in the provisions of Article 55 paragraph (1) 1st of the Criminal Code, therefore the position The defendant in this case is a person who participated in committing criminal acts (medepleger).

The above case constitutes one of the criminal acts of corruption through the Hand Catching Operation regarding extortion by state officials. The data presentation shows that: The due process of law system in law enforcement in our country mandates a correct and fair law enforcement process, not on the basis of stigma let alone hatred towards citizens who are not necessarily guilty of something that is suspected or accused of them.

The legal construction built by the panel of judges is based on three main elements in criminal law. First, the criminal aspect, the verdict that has been passed has fulfilled two principles in criminal law. Secondly, the aspects of the criminal act, the defendant's actions as stated in the subsidiary indictment were proven legitimate and convincing to have committed corruption under the classification of extortion. The three aspects of criminal responsibility or the element of guilt, this aspect are fulfilled by the testimony of the accused and witnesses at the trial. The principle of criminal law used in making the decision in this case consists of the principle of legality which means "An act is not punished, except based on the strength of the existing criminal legislation". In addition, the panel of judges in their legal construction also uses the principle of credibility, 
namely the principle of "no crime without error". The two principles constitute a balance building between legal subjects (actions) and aspects of people (mistakes). So that the judges' scales of justice have met legal justice.

The elements of the criminal act or the act of the defendant are proven legally and convincingly against the law as formulated in Article 12 e Act No. 31 of 1999 jo. Act No. 20 of 2001. As a State administrator, a defendant receives a gift or promise as referred to in Article 5 Paragraph (1) letter a, namely giving or promising something to a civil servant or state administration with the intention of unlawfully benefiting himself or another person, or abusing his power forces someone to give something, pay or receive a discounted payment or to do something for himself and who participates in the act. This aspect is the application of the legality principle of the panel of judges.

Meanwhile, the aspect of criminal responsibility committed by the defendant was proven from the elements of guilt committed by the defendant, including: deliberately proposing the idea of forming a committee to smoothen the implementation of the Prona process, where the Defendant stated "later the Chair of the Prona Committee will let me know because I know better. is me"; In addition, the Defendant made a Letter regarding the Settlement of the Administration of Land Certification for Unsettled Residents, and was signed by witness SHS, which contained, among other things, "if the community requesting a certificate does not heed / has good intentions, the Village committee will be forced to come to you and withdraw the certificate from Your hands and the Committee will give you 10 days from the time this summons is delivered to you or it will be blocked".

Thus the judge in deciding this case is based on the principle of balance or monodity in criminal law, namely the principle of legality in article 12 e Act No. 31 of 1999 Jo No 20 of 2001 and Article 55 paragraph (1) 1 of the Criminal Code. Meanwhile, the application of the principle of culpability or the principle of "no crime without error" occurs in proving the elements in the single indictment of the public prosecutor. The legal fact that the principle of liability is used is evidence of the intention of the defendant who from the beginning had designed the existence of a mensrea (intention) as chairman of the Prona committee, until deliberately breaking the law because the determination of the cost of a land certificate which should have been free (terms and conditions applied) was decided by one side.

\section{Closing}

The legal construction built by the Panel of Judges in the case of extortion qualification corruption cases Number 21 / Pid.Sus-TPK / 2018 / PN Smg, fulfills the provisions in the Criminal Law. As the science of criminal law explains, criminal law consists of two main principles in deciding, namely the principle of legality and culpability. The defendant was proven to have violated the law in the provisions charged by the public prosecutor, namely Act No. 31 of 1999 Jo No 20 of 2001 and Article 55 paragraph (1) to 1 of the Criminal Code. Meanwhile the defendant was proven to be deliberate, at least knowing it as an intentional element, designing the Prona committee, setting Prona's fees, and issuing a "threat" letter to the applicant which should have been free (with certain conditions). 
According to the Panel of Judges, such legal facts are sufficient to prove that the defendant was deliberately involved in the criminal act of corruption.

Based on the conclusions that have been made, the public prosecutor should be more courageous in giving an indictment with a single accusation. So that from the start, I was sure of the charges given, especially from the collection of materials and information through a catch operation.

\section{References}

\section{Journals:}

[1] Arief, Barda Nawawi. Kebijakan Reformulasi Ancaman Pidana Mati Tindak Pidana Korupsi dalam Peraturan Perundang-Undangan, MMH, Jilid 42, January 1, 2013.

[2] Djauhari, and Selamet Agista Erikha Bhakti. Upaya Pencegahan Tindak Pidana Korupsi Melalui Peran Serta Masyarakat, Jurnal Hukum Khaira Ummah, Vol. 12. No. 2 June 2017.

[3] Lawrence M. Friedman, “On Legal Development” In: Rutgers Law Rivies, Vol. 24, 1969.

[4] Siregar, Hulman . Rumusan Pidana Dan Pemidanaan Tindak pidana Korupsi Yang Merugikan Keuangan Negara Serta Permasalaan Dalam Penerapannya, Jurnal Daulat Hukum Volume 1 No. 1 March 2018

[5] Sri Endah Wahyuningsih, and Koko Arianto Wardani. Kebijakan Formulasi Hukum Pidana Mati Terhadap Pelaku Tindak Pidana Korupsi Di Indonesia, Jurnal Hukum Khaira Ummah, Vol. 12. No. 4 December 2017.

\section{Books:}

[1] L.J, Moleong. (2004). Metodologi Penelitian. Bandung: Remaja Rosda Karya.

[2] Sudarto. (1981). Hukum dan Hukum Pidana. Bandung: Alumni.

[3] Sutedi, Adrian. (2009). Aspek Hukum Pengadaan Barang dan Jasa dan Berbagai Permasalahannya. Jakarta : Sinar Grafika. 